\title{
THE INTERPRETATION OF THE REPORTS OF WATER ANALYSFS.
}

\author{
I3y J. F. PURVIS, M.A., F.I.C., H.C.S. \\ Lecturer and Sacominer in Sinte . Dedicine, Unirersity of Cambridge. \\ Read at Sessional Meeting, Cambrirge, July 15th, 1905.
}

W IIEN I real Professor Woulheal's paper on "The Water siuply Prublem in Rural Districts," I thomght that, in croler to illustrate the chief point he makes with regard to co-operation, I minht give the analyses of the waters from two village pumps which he and I examined some two or three months agn. These pumps supplied two villages in the South of Engrlanil.

A. B.

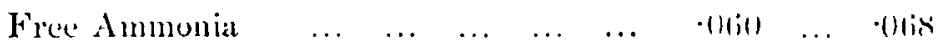

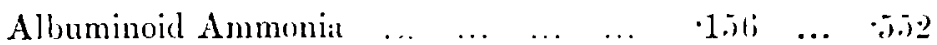

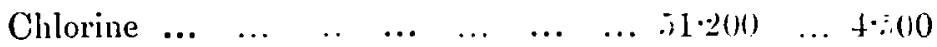

Oxygen absorbed in : homs at $\left.x()^{\circ} \mathrm{F} . \ldots \quad \cdot 100\right) \quad \ldots \quad \cdot 070$

$\begin{array}{llllllll}\text { Nitrogen as nitrates } & \ldots & \ldots & \ldots & \ldots & \cdot x(0) & \ldots & .500\end{array}$

You will notice the very con-iderable amount of the two ammonias in A, almost by themselves sufficient to condemn the water. You will notice the enormous amount of chlorine. I put these numbers in parts per hunded thousand, not in grains per gallon. Iou will notice that the oxyen absorbed is larege. I do not suppose that the whole of the chlorine comes from sewage contamination, or from surface water contamination. I am inclined to think there is a cleposit of some salt of chlorine in some stratum through which this well is bored, and that it is partially dissolved by the water in the form, say, in part of ammonium chloride, or it may be, in part, of other chlurides. I clo not think it is whoilly ammonium chloride, beanse I think the amount of fiee ammonia would then be 
considerably larger. Of course an analysis of the mineral constituents is necessary to decide. You will notice that the amount of nitrogen as nitrates is very high. Now, taking the analysis as it stands, the water must be condemned for drinking purposes. Also, not only does the chemical analysis condem the water, but Professor IVoodhead condemns it from a bacterial analysis.

The water B is also from a village pump in the South of England. Fou will notice agrain the large amounts of the two ammonias and of the chlorine, and also the suspicious amount of oxygen absorbed. I have very little doubt that this well water is contaminated either by sewage or by surface drainage. Bacteriologically Professor Woolhead confirms the judgment that this is a water which must be condemned. These analyses are two of four waters of four different village pumps, all of which were condemned. I have no doubt that the number ran be multiplied by a thousand, or even by ten thousand, where people are regularly drinking water bad for their health. All over England people are regularly drinking such foul waters; and the wonder is that epidemics are not more frequent. I do not saly the people would suffer from trphoid or any other bacterial disease, such diseases would show themselves sooner or later, but I do say that water containing such large quantities of organic matter tends to lower the system in such a way that it would never be normally strong, and also be a cause of a tendency to infection. As a fact, several people had suffered from diarrhira caused by drinking these waters. These two instances illustrate Prot. Woolheal's argunent with regard to co-operation: that if you want a hygienically pure water, the best plan would be to have some central organisation which can supply a large arca. You will then get a constant supply. Iou could take the proper steps to see that the supply is always chemically and bacterially pure; and you can much more easily trace the advent of any dangerous appearances in the water, and so lessen the chances of the spread of infection, and you would also raise the general standard of liealth. I think that the supply of grood sound water slould be as much the care of a central authority as is the supply of a good education. It is to be hoped that steps will be taken hy some such borlies ats the Comnty Councils to realise this supply.

My own particular part of the discusion is to illustrate the limitations in the reading of reports of water analyses. Witl regarel to the two waters, $A$ and $B$, there is no doubt that both would be condemned. But that is not always the case. The reading of a report is not always so easy. Sometimes a medical ofticer of health has to deal with the analysis 
of a water which does not tell so clear a tale. On the other hand (and this is the result of $\mathrm{my}$ own experience) a water on analysis sometimes appears to the chemist as exceedingly dangerous. What $I$ mean is this: $I$ have here a water analysis, the figures of which I extracted from an official report-

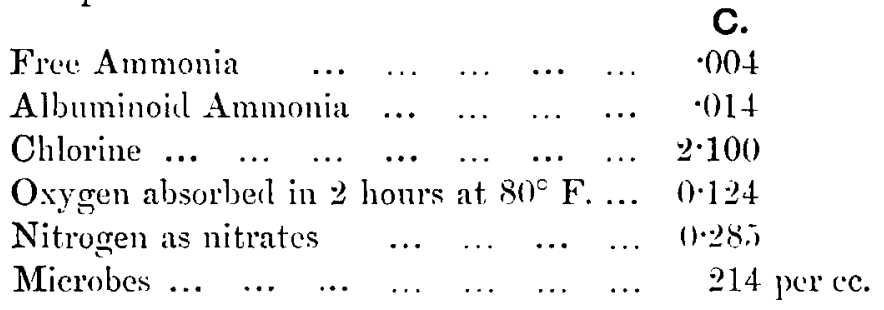

In this analysis you will notice that the two ammonias are rather high. A chemist taking the analysis by itself would look upon the water suspiciously. The elhlorine figure is not high. On the otlier hand, the oxygen absorbed, a most important factor in a chemical analysis of water, is very high. Now, taking these three constitnents by themselves, and comparing each with the others, a chemist would, I venture to think, condemn the water as suspicious. I certainly should. What is the result of the bacterial analysis? Notwithstanding the three high figures just mentioned the bacterial analysis is low ; that is to say the water contains 214 microbes per cubic centimetre, and I believe this figure would be jassed by the bacteriologist. The water was supplied to the East End of London when this analysis was completed, and it is a good water. So far as I an aware no typhoid clisease nor any particular bacterial disease which might have its origin in bad water was prevalent in the East End as a result of drinking this water. $\mathrm{My}$ point is, that if you take the ('hemical analysis of this water by itself, a chemist would reasonably vicw it with gratre suspicion, even if lee might not condemn it.

Now consider the next water analysis-

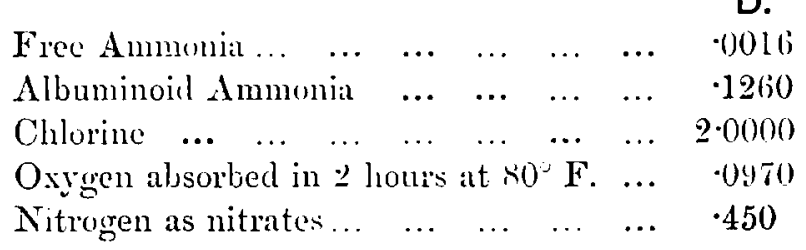

This analysis is mown. You will notice that the free ammunia is rather low. It is more or less well within the danger line. The albuminoid ammonia is very high, and by itsclf a clemist would riew it with grare 


\section{The Intorpretation of the Reports of Wuter Analysse.}

suspicion. The chlorine is low. The oxygen absorber is suspiciously high. Nitrogen as nitrates would pass. There would be no rlanger there. Taking the analysis as it stands then, it might be argued that these figures might be due to vegetable contamination. It might he so. But a chemist would, at any rate, argue that the albuminoid ammonia and the oxygen absorbed are higher than a normally good water should show, :mul until I knew more of the history of the water I should be inclined to condemn it. Now this water was supplied to the city of Westminster at the time of the analysis, and so far as I know was a good water from a lyygienic point of view, anyway, no bacterial disense was prevalent at the time. My argument is, that looking at the water from a chemical point of view, and knowing nothing of its origin or its distribution, you would look upon it with a certain amount of suspicion.

Take inother water, E--

E.

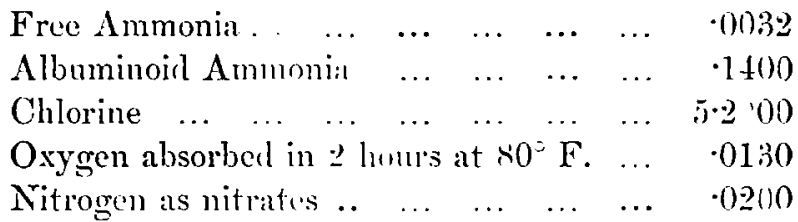

This is a water which I also analysed. I linew nothing about it: purposely I was told nothing about it; nothing of its origin; nothing of its history. You will notice the free ammonia is fairly low; you will notice the albuminoid ammonia is very ligh ; you will notice also that the chlorine is very high; the oxygen absorbed is not clangerous, in fact, it may be considered to be low when compared with the figure for the albuminoid ammonia. The nitrates are negligible. Now, viewing the analysis from a chemical point of riew, and knowing nothing of the history of the water, you would conclemn it: primarily, because of the high albuminoid ammonia, and secondly, because of the chlorine. It is true there might be some deliberation in the final judgrnent, because the oxygen absorbed is rather low, but taking it as a whole the analysis tends to show, I think, that it is a dangerous water. Well now, what is the history of that water? It is a leep-well water coming from the Lower Greensand. The high chlorine figure is probably explained by the origin of the water from the Greensand strata. As you know, the Greensand rontains a large amount of chlorine as chlorides; also, the albuminoid ammonia is pussibly due to some vegetable contamination. If it were not Ilue to vegetable contamination the chances are that the oxygen absorbed figure would be considerably lighter. My point is that looking at the 
analysis as it stands you would condemn the water as beingr suspicious, and you might easily condemn it as dangerous. Previous analyses had been made of this water, and they showed by the two ammonias a considerably greater contamination. The well was put in good order, and the analysis $E$ is the result of an analysis completed some weeks later. It showed that the two ammonias were going down as compared with the previous analysis. I venture to think, if the analysis had been ropeated, as it ought to have been repeated, some five or six weeks later, that the figures would have been considerably lower. Anylow, there was no epirlemic dne to any bacterial diseases.

The principal point I wish to make with regard to these three waters is that, taking the analyses by themselves, you camot deliver a final judgment as to whether any of them is good, bad, or indifferent. If you ret similar analyses you will probably look upon the waters with grave suspicion. And so I think that some rules are necessary with regard to the instructions to the chemist, some of the more important of which I now suggest.

1. I hold that the chemist should know the whole history of any water given to him for analysis. As I say, I condemed the water E as dangerous. The condemnation was only modified when I knew the complete history of the water. Therofore I say, if you are to have any satisfactory results from the figures of a water analysis, the chemist should know the geological character of the particular district. He should know the gencral saline constituents of the geological strata, because, if you look at table $A$ as an example of what $I$ suggest is pussible in solution, you might get considerable amounts of chlorides in the strata which would contaminate, as it were, the particular water. Only a few months ago I "xamined a deep-well water of which I knew nothing. Chlorine as chlorides amounted to sume 25 parts per 100,000 . The amount of free ammonia and the amount of albuminuid ammonia were proportionately large. The oxygen absorbed was excecdingly small. For at time there was some difficulty in reconciling the figures of the analysis. Finally it apleared that in this well there wats no sewage contanination, and no surface contamination. The cause of the large amount of chlorine as chlorides, and the free and albuminoid ammonias, was duc to the fact that the water lad dissolved out of the strata a definite amount of ammonium rhloride. Now, as chemists know, ammonium chloride is easily disassociated or decomposed, aud part of the ammonia comes over as free ammonia. It does not end at that. The ammonia distills very slowly but continuously, and you finally give it up as endless, and proceed with the albuminoid 
ammonia distillation. It is then found that the alkaline permanganate turus out a large quantity of ammonia, which is put down as albuminoirl ammonia, whereas, as a matter of fact, it is nothing but the residum of the original ammonium chloride. Therefore, I say, a chemist should know the grological history of the water he is to analyse. He sliould know where it has come from.

2. He should know the method of storage; he should know how it is stored.

3. He should know the method of distributing the water, because, as you know, there are serious sources of dauger arising from imperfect storage.

4. He should also know the rainfall just before the analysis is made. If you get a heary rainfall just before an anilysis you generally find that the amounts of the constituents differ very considerably from an analysis completed before the rainfall.

5. The chemist shonld visit the place himself. He should sec the mutlet; he should examine the surface drainage; he should see the cover of the wells. He should see if the gathering ground is properly guturded, and if it comes up to the ideal condition of water supply and protection mentioned by Professor Woodhead. He should sec if the well is as properly protected as Professor Woodhead's example. If he does not, depend upon it there will be some doubt in lis judgment of the analysis.

ti. Mlso, I do not hold that a chemical analysis is sufficient by itself. I think a bacterial analysis should always be completed as well. Nor should the final judgment rest with the chemist. The final judgment should rest with the chemist and hacteriologist in collaboration. A bacterial eximination slould be done, because, as you know, you may have a water which, from a chemical point of view, is organically pure, but it mily still contain weruss of clisease. On the other hand, you may have a water bacterially pure, but which may, from a chemical point of view, be suspicions, or even clangerous. I clo not say cither will of ten occur.

i. Also both chemical and bacterial analyses should be done regularly and frequently, as is done in London.

There is just one word I would like to say with regard to the liardness or rather the softness of water. This is a danger which $I$ think has been rather neglected. The more clramatic action of bacteria has, in these later years, tended unconsciously to put into the background dangers which may arise from the use of soft waters. Take for example this particular water :- 


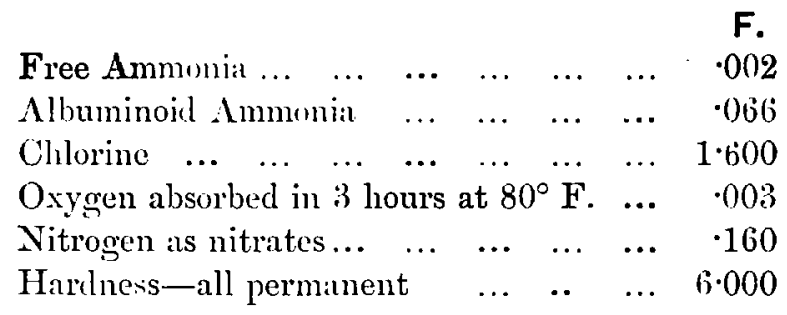

The free ammonia is low. If you compare the allbuminoid ammonia with the oxygen absorbed, it is possibly due to vegetable contamination, as is inclicated by the low figure for the oxygen absorbed. The chlorine figure is cxceedingly low. The danger arises, not from the organic constituents, but from the softness of the water. Its hardness or softness is determined by the low figure of 6 . It is a dangerous water. In such a water, in continual use and distributed throngh lead pipes, the danger is that the water might dissolve a certain amount of lead. A striking example of this particular danger occurred in my own experience. A water was sent home from a Dartmoor district, and what was the result of the analysis! As regards the organic constituents the analysis showed that it was a very pure water. It was almost wholly free from the two ammonias. The chlorine was about 1 , and the oxygen absorbed was very small. I found on further investigation that it contained half a grain per gallon of lead, dissolved by the water from the lead pipes. Now this district had not suffered from lead poisoning as far as I know ; but it lad suffered, and may be suffering now, from a species of gont. I do not know if grout is a result of lead-contaminated water, but the fact remains (it may hare been a coincidence) that in this particular district some forms of gont were strongly prevalent. I am inclined to think that the gout was due to the large yuantities of lead contained in this exceedingly pure water.

Therefore, apart from the general principles which we have been discussing with regard to organic pollution, I saly that nut only must the organic pollution be taken into consideration, but also the hardness or softness of the water. If a water analysis shows that although the organic constituents may be exceedingly low, the hardness is also exceedingly low, then I think it is as much the duty of the Medical Officer of Health to point to the dangers which might arise from lead poisoning, as it is to lay stress upon any possible dangers from the organic constituents. 
Professon Mchexy Hugnes (Cimbrilme) thrught that in such questions as water supply, the advantiges of co-operation between those who followerl different brinches of scientific inquiry nust be obrious to those who had listened to the two papers just read, and ho was entirely in accord with Prolissor Sims Woodlead and Mr. Purvis that there slould be co-operation also with regard to the practical carrying out of schemes for the supply of water. The population shifted about from alsels where water wals alsundant to areas where it was scarce, and the question of the supply of watep should not be left to the discretion of ignorant people or the liberality of corporate budies. They already recognised control in details of municipal lili. No one was allowed to erect a building in Cambridge in such a way as to interfere with the traflic or public convenience generally. Everyone had to submit plans to the Town Council specifying what he proposed to do. Thit was not left to the public spirit of companies or of individuals. There would be no greater hardship in having to submit every scheme for wells or drainage in town or country to a properly constituted authority. Whrn a man sumk a cesspool his olject was to get rid of liquid, and so he went down till lie found a stratum so pervious that it would absorb and carry it all away. Anotler nan close by wanted water for domestic purposes and, knowing nothing of the cesspool, sunk a wrll down to the very same porous stratum and drew polluted water. The menhods adopted for the purpose of preventing surface contanination at Maidstone would not do for the neighbourhood of Cambridge. Of course, when mischicf had been done, and could be proved, there wure authorities who might be appealed to and who could take action, but more than that was wanted. They wanted prevention, not cure only. No well or cesspool should be sunk without being duly registered, as underground workings were, in a mining recorl oflice, for the guidance and protection of later explorers. He would, howerer, go further than that, laving regard to the larior centres of population as well as to rural districts, to which it more obviously applied. He thouglit that there ougrat to be a compertent body to control the water supply of the whole country. It ouglit not to be left as now to be scrambled for. They might not be able to formulatro exactly what the constitution and powers of that body should be, or the nature of the control exercised, but there should be some central authority for drawing up a gencral scheme for the distribution of water to the great centres of population, and to every homestead. Large water schemes were brought before Parliament and, if there were no oljections to the character of the water and the finaneial proposals, they generally got througl, but there was no ofliee or minister whose duty it was to control the distribution of this, the most essential material of our individual and common life. Thus we had valleys in Wales dammed up, and lakes in the north of England raised, without any general scherue being worked out by which it might be pussible to allecate the suurecs of supply in a less extravagant minuer, to feed the smaller towns and rural 
dist ricts on the way, to provide everyone with water, the chicf necessary of life, and to save thousands (especially of the poor) from being poisoned. The evil was very insidious; a mild attack arising out of neglect of precautions might $b_{x}$ : handed on in a more virulent form, and even where no fatal or serious consequences followed. there was often a general lowering of vital energy which might lead to dangerous results. Nature, lowever, was very kind and removed many a source of danger to which they had laid themsclves open. For instance, a quarter-mile of tumbling water would, he believed, oxidiz' the sewage of a town as large as Cambridge, but the gently-flowing Cam could mot do that for them so rapidly. Then their porous strata provided an excellent filter, placed by Natur. in the path of percolating waters; and even when they had got some of the evil microbes into them, they often did no harm, as they did not find a suitable soil. But they should not presume upon that frequent immunity.

Mr. ITrabert Genge Formman (Chairman, Cambridgreshire County Council) referred to the tables exhibited by Mr. Purvis, and asked for some explination of "oxygen absorbed" as a factor in analysis of water for orwallic ingredients, assuming that the absorption was not mechanical but purely chemical, and was adopted as a measure of the amount of organic impurity neutralized by the absorbed oxygen, based on some quantitative standard. Speaking on the pesition of County Councils as controlling authorities in matters of public health, he pointed ont that, tbough their powers under the Local Government Act, 1888, are extremely limited, under the Act of $189+$ they can, in the event of a proper complinint being lodged with them, and its allegations being sustained on a public incuiry, deal in a very drastic and complete manner with any distriet council which fails to discharge its duties under the Public Health Acts. No complaint in this matter had, however, come before the County Council of Cambridgeshire at any time. Je pointed out also that a County Council baving to act upon such a complaint in a judicial spirit, and to establish the ficts of the cise as between the parties, cannot with propriety initiate any such proceedings, and that thus, for want of a complaint, cases of defult of minor local authorities may not receire adequate attention. In matter's of genoral sinitition be mentioned the important powers of County Councils for the promotion of a general system of isolation hospitals, which can be made affective by il wellarranged plan of contributions in aid of buildings and equipments from the general county fund, and emphasised the practical value from the point of view of sanitation and Public Health of the Midwives Act, 1902, as administered by the Central Midwives Board (upon which body he is the representative of the County Councils Association), and by County Councils as the local supervising authorities. He dealt finally with the administrative difficulty arising from the non-natural character of the county area as a water-control district in reference to watersheds and hydro-geological basins, and expressed the view that administrative efficiency could only be completely secured by the creation of natural rot. xxvi. ro. 8 . 


\section{Rural Water Supply and Interpretation of Water Analyses.}

areas, combining watershed boundaries as closely as practicable with those of unit areas of underground water supply.

Mr. Josepir Marrix (Chairman, Isle of Ely County Conncil) sail he must take exception to the suggestion that, when a simple of water was sent for analysis, the nature of the soil and other surroundings should be given, as he considered that such information might more or less influence the analyst in making his report of the purity of the watir. Doubtless the water supply to villages and small towns was one of the difficult questions of the day, especially in the Fen district in which he resided, as the expense in procuring water from the Chaili or Greensand was prohibitory. The rivers were the natural supplies of water, and he considered that power should be given to some authority to enforce the Rivers Pollution Act $(1,5,5)$ without baving to obtain an injunction, which was always expensive and slow in progress.

Dr. Thoxaro) P. Kisicerer (Wourester Polyterhnir Institute, Worcuster, Mass.), said he laid listened with great interest to the two papers, and hat "njoyed greatly the privilege of meeting so many men well known in the Unitud States for their work in sanitary soience. In America they looked up to the work that harl been and was being done in England, and studied most carrfully the results of their work on sanitary problems. The danger from pollution of rural water supplies was most admirably described by Profinsor Woodlanad, and what had been done in 1 be neighbourhood of Cambridge to diminish that danger was a lemion showing whilt could be accomplished by lonal authorities. Would that the suggestion of Professor Woodhead as to "entral (ontrol of the water supply of the rural districts inight, ats it should, beile fruil. Typhoid fever, the most serious and the prineipal danger from the use of polluted watir, was, he thought, not nearly so much an urban as a rural discasc; the deatlirate per hundred thousind of the living population was much greater in ruril districts 1 hin in ifies, and the cause of this was without question that water used for drinking purposes in the country was much more likely to be polluted than it was in the city. The character of a water supply of a city was linown, and, if pollutel, precautions could be taken regarding its use. In the rural districts (especially in the United States, where each housholder was, as al rulc, supplied with water from a well on his own land) the danger from pollution was very great. A well was dug without any regard to location, and in many casiss one of the sources of supply of the water in the well was a cesspool sunk in 1 h. near neighbumbos. How this could be prevented was diflicult to saly. 'The authorities rould cortainly close the well if they knew it was polluted, but this knowledge was gencrally only obtained after a case of typhoid fever had caused an analysis of the water to be made. Much could be dome in the Lnited States if the Boards of Health had the authority to appoint inspectors, whom the bousilolder would hare to consult before sinling a well upon his land. Furthre, if 
when a well was dug thr plan mentioned by Thresh in his book on witer supplies were more often followed (i.r., of filling the well to the height. of hight water with gravel stone, and from this point to the top of the well with sand, and sinking the iron pipe to the botton of the gravel) danger of pollution of the water would be greatly diminished. Naturally following, came the question which had been so ably dealt witl by Mr. Purvis in his paper, "The Interpretittion of a Water Analysis." Dr. Kimnieut agreed with Mr. Purvis when lee silid that whenever it was possible a survey should bu made of the river, pond, lake, or well from which the waler was derived; for rory mush depended on nat ural ronditions surrounding the waler supply as to the significance whirh slowkl be placed on the dita obtained in the anilysis. P'ersonally, he placed most dependence on the free and albuminoid ammonia, and the nitrogen as nitrites and nitrates; and not as much stress on the oxygen consumerl. High fire ammonia in ground water, without pusulting from some 'xplainable cause, was a dangel signal, as was also alluminoid anmonia. [u surface waters which had at high rolour, high alhuminoish ammonia was not so significant, as it might he dur. conly to regetable matter derived firom peaty or swampy soil. Nitrogen as nitrites should certainly not br over 0002 parts in 100,000 parts in unpollured ground water ; while high nitrugen as nitrates indicated that the water at $40 \mathrm{~m}$. previous time contained moxidised nitrogenous matter. Wher the nomal chlorine of the water in 1 lue region was known, as was the caise in all parts of Iassachusetts, the chlorine figure gave valuable information. 'The oxygen consumed he did not regard as io valuable a factor, as it only indicat ${ }^{2}$ oxidisable. matter and gave no infurmation as to whether it was of animal or vegretals, migin; further, none of the methods in use for determining the amount of "xygen wnsumed gave the total amount, the amount found dipending antirely upon the method used. I bacterial eximination should be included in all sanitary analyses of water, the quantitative determination and the trest for harilli coli. IIr did not quite agree with Mr. Purvis as to what he said aluout sift water. For general houselolel use witt water was to be prefered. There was no question as regalds thr action of solt water on lead, but learl pipes slould nerre le used in well;, and a special iron pipe should be weed for conducting the water inside the louse for drinking and rooking purposes in the calse of city supplies.

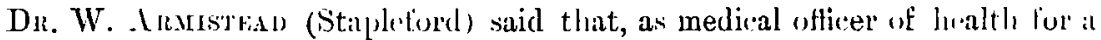
larere area in the administrative counties of Essex, West Suffolk, and Cambridge, he had for more than 30 years been brought intimately in rontact with the many difficulies which arive in connection with the water supply problem in rural districts. The real deterrent in connection with the adoption of a water scheme for a village was the cost, and when the village was situated on the high boulder clay area at an elevation of over $300 \mathrm{ft}$. above ordnance datum th. clifficult ies war.

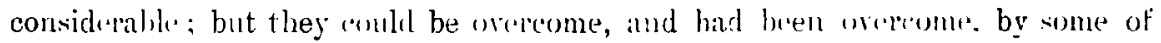




\section{0 liural Waler Supply und Interpretation of Water Analyses.}

1he Rurnl District Councils, by boring 250 or even 350 feet through the Boulder Clay into the Claalk and lining the bore-tube with steel tubes, from which the water was pumped by a borehole pump into a reserroir on ligh ground and distributed in pipes to standpipes in the village; the power used for pumping being either an oil engine or a windnill. These schemes were, however, very costly for villages with a small population and a small rateable value. Some villages which were formerly supplied by shallow dng wells, liable to surface and sewage pollution, were now supplied by wells bored 100 feet or more into the Chalk and lined with iron tubes, the water where it rises to within 20 feet of the surface being raised by hand-pumps bolted on to the iron bore-tubes, so that there was no possibility of pollution. Some of these villages, which were formerly very liable to outhreaks of typhoid fevel caused by pollution of the water supply, were now free from that discase. Other villages on the Gault bad been supplied by wells bored through the Gault into the Lower Greensand, from which a good supply of soft water had been olstained. It was at first proposed to bring before the mecting the distribution of water in county areas. With respect to the administrative county of Cambridge, all the area to the surth and wast of the courty could be supplied from the Chalk, the only questions requiring serious consideration being the lxat scheme for obtaining the water and the cost. He called attention to the fact that a few years ago two schemes were brought lefore Parliament for obtaining a layge supply of water for South Essex from the Chalk in the watershed of the Cam. Fortunately hoth these schemes were successfully opposed, but similar schemes might again he brought finward it nothing was done to utilize this excellent source of water supply for the comty, including that part of Essex which is in the watershed of the Can.

Mr.J. L. Llobiscitos, J.P. (Vice-('haiman, Ely Ruril District Council) drew attention to a juint connected with water supply which hald not been toucherl upon, riz., the difficulties caused by the pollution of river's. He lived in the midst of the fen country, where it was impossille to get water by sinking wells, and where the supply from any efficient springs would be from ten to twelve miles distant. A widle good river passed through the district, and seemed to form the natuml supply. Tha, howerer, was polluted by a city about five miles higher up the strem, which poured its sewage in a erude state, and without any pretepce of treatment, into the river. A strong representation was male to the County Council to put into operation the provisions of the Rivers Pollution Act, but this was refused, on the ground that the whole county would have to pay the expenses of it whilst only one village would benefit. Then an application was made to the Local Government Board to do it, but tley refused to act, and the only course then was for the District Council to apply for an injunction, and this was thought too costly for them. The supply of water was of national importance, and that leing so he considered that inspertors should le appointed 


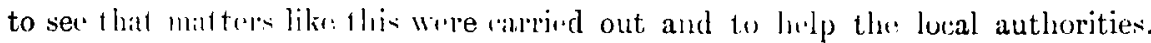
His expreience wils that everyone was very ready to criticise. What was wanted was not merely criticism, lut real help and adrice. This seemed to him to he a matter most closely connereded with water supply in rural districts, and he was glad to have had a chaner of hringing it hefore the attention of the members at that moeting.

Dr. Busiridu Ansivgson (Cambridge) agreed with Professor Wuodhead that the establishment of water boards would probably he needful to carry into effect his object of conveying water from an area of alundant supply to one of watcrless geological strata. There were many clauses in the Public Tlealth Acts imposing on owners of houses and local anthorities the duty of providing a sufficient quantity of pure water ; but not one of them quite met the olject indicaterd in the paper; the only legal power for provision of water outside a district was contained in section 61, Public Health Act, 1875: "Any local authority for the time being supplying water within their own district maly with the sanetion of the Local Government Board supply water to the local authority of any adjoining district on such terms as may be agreed between sucle authorities or as in case of dispute may be settled by arbitration in mamer provided by this Act"; and in suction (33, which gave power to any water company 10 contract for the supply of water with any local authority.

Mr. C. G. Moor (Iontlon) rilid it was interesting to hear that a London company lad refused milk from a Cawbridgeshire firm on the ground of a had water supply, and mentioned that at Oxford the local penple, being unable to sell milk from a certain farm, sint it to London. He feared that all London milk-buy ress were not so punctilious as the one referred to by Dr. Sims Wrodhrad. It had been stated by Mr. Purvis that organic matter in water was a calse of illhealth. 'Tlis was the kind of statement that might be copied from one text-book (1) another, but le was not aware that any real evidence existed for it. In the case of two waters referred to, it was mentioned that they were condemned aliki. by independent chemical and bacteriological examination, and he did not doubt but that this would frequently occur. Ho had several times expressed a desire to see a tibulated statement of results on, say, a thousand samples, giving the bacteriological and chemical results, togrether with a description of the surroundings of the source of supply, and a record as to whether the water in question had before or since produced ill afferts on health. He desired to draw attention to the limitations of both hacteriological and chemical analysirs, inasmuch that while both of these methods could point unt dinger, they could not logically be used as a cruarantee of safety. Some persons having had a particular well analysed, sily a dozen years ago, would not liear of any possible dinger in the future, and regarded the certificate of analysis ax a kind of magic cbarm against pollution for all time. As an insturee showing the necessity of inspecting the 


\section{- 442 Rural Water Supply and Interpretulion of Water Analyses.}

source of a river supply, MIr. Moor mentioned the calse of a city deriving it: water supply from a river which received a large quantity of sewage from a town some twenty miles away. The water was of excellent quality so far as chemical and hactoriological examination showed, hut for all that there were periodical recurrences of small groups of typhoid case's, which appeared to coincide with the scraping of the filter-beds. This was probably 1 be case in many towns which clerived their water supply from rivers, as ther. conld hardly be a river in the whole country that was not used as a sewirge outfall by some of the towns or villages on its banks.

Dr. Saricie (Colchester) remarked that the subject ("ould be dealt with from two points of riew, that of the analyst and that of the achministmator. As one who had frequently to look at the matter from both standpoints, he felt he could better appreciate the difficulties of both, for although Colchester was an urban district, yet the area was very large, and comprised a consideralule purely rural population. Speaking first from the administrative aspect, there was no doubt that in rural districts the question of a satisfactory water supply was often a) difficult one. $\Lambda$ s a lacteriologist he had, not unfrequently, to rondemm il rural water supply, and that miglit be a simple matter; but the difficulty was that aftur the water supply had been stopped, there was in many cases no other source obtainable, and the last state was worse than the first. ITe bolieved that one way out of the difficulty was in regard to better construction of shallow wells. Slallow wrll water is usnally lnoked upon with suspicion, frequently. with justifialule suspicion, hut often it was the only source arailable. It, lowever, many of these wells were properly made, they could be uscil to give satisfactory and drinkable water. For example, about a year ago be condemned the water from a shallow well, which was thoroughly bad. That was an easy miatter, but the difficulty was how to supply the 1 wo cottages concerned with pure water since no other source of supply was arailable, and to sink a deep well was ont of the question. The drainage was hadly laid and defective: that was relaid and made satisfactory, the well was deepenerl and made impervious to a depth of fifteen feet, with also a good backing of elay, while it was properly covered in and fitted with a pump. The water is now a satisfactory one. He wats very glad to notice that such an authority as Dr. Thresh adrocated the use of properly made surfice wells in suitable cases. Imong the administrative difficulties may be mentioned the peculiar wording of section 70 of the Public. Health Act, 1875, which requires a water to be so polluted as to be injurious to health before the well, etc., can be closed. A water may be sewage polluted, but it is not so easy to advance evidence that that water is injurious to health, or to prove thiat the two terms are identical. Dealing with analytical questions, he could fully endorse Mr. Purvis's remarks as to the need of data griving the source, etc., of the water before the interpretation of the analy tical results could yield their greatest value. The old bad notions were dying hard, and cluring the 
past few years he had frequently had waters sent him for analysis about which le was refused any information, and was indeed looked upon with suspicion herause he asked for it. For an important matter such as ascertaining whether a water was fit to drink or not, there was no doubt that the more information given the better, and results must always be interpreted in the light of topographical information. In regard to the methods of analysis, as he had frequently pointed out, he was convinced of the great superiority of bacteriological over chemical methods. The examinations made of the Bridgend water supply served as a good illustration of the relative value of thesc methods of investigation. The water supply was from springs issuing from the Carboniferous Iimestone, and topographirally, until condemned bacteriolugically, no fault was found with it. In 1901 he condemned it on the results of its bacteriologieal examination, while the chemical analysis, made with similar samples in the same laboratory, showed no evidence of pollution. Right up to October, 190\%, frequent (xaminations yielded the same results, the bacteriolngical data furnishing marked evidence of pollution, which the chemical analysis failed to show. Subseguently a Iocal Government Board Inquiry was held, and Dr. Klein's bacteriological examinations quite confirmed his results, while Dr. Bulstrode traced the contamination. What he liked to do in investigating a water supply was to go and personally examine the sources of the water and to collect his own simples for bacteriological examination, making also chemical examination if required, while of course for poisonous metals and hardness, chemistry alone was available. In regard to the roxed question of standards, chemical or barteriological, there was su doubt that they were nevir absolute and only helps, useful if not pushed too far. It was impossible to set up absolute standards applicable to all waters.

Mr. Wesi Kricinss (County Analyst, Cambridge) entirely agreed with the previous spenker who said that it was impossible to fix any standard by which waters from all sources conld be condemned: a feature that would be satisfactory in one water might absolutely condemn mother. He was struck by the simplicity and apparent efficiency of the means adopted at Maidstone to preserve the various springs from pollution; and if the same could be applied to improving the purity of waters obtained from surface wells in isolated rural districts, he thouglit it would be extremely valuahle in many of the villages around Cambridge. With regard to the interpretation of the results of analysis, apart from any outside information, it depended upon whether the analyst was repuired to pronounce judgment on the sample of water actually before him, or to predict whetber a certiin well would be capable in the future, next week, next montl, next year, continuously to supply pure and wholesome water. $\mathrm{He}$ thought there was considerable difficulty in getting those particulars. Some yeal's ago, the medical officer of health of a large borough, of which he was the water examiner, urged his town council to pass a resolution that those particulars should be supplied ly the jnspector with each sample. That resolution 


\section{4 liurral ITuter Supply and Interprotution of Water Analyses.}

was not carried: it seemed to suggest to the minds of the council that if the analyst could not condemn the water on 1 ht results of his chemical analysis, he was to be induced to do so on the out side evidnce supplied by the person who took the sample, pussibly a prejudiced person.

Mass C. Cochraxe (St. Neots) said that the carrying out of all satisfactory work must depend on individuals, and every individual there probably had some influence in his own village; and if so, should use that influence, in his 1111 village if he had the rourage, or in a neighbouring village. Much might be done at thifling expense, such as raising the tops of wells and putting a sound cover, replacing a worn-out filter bed, cleaning a drinking-pond, railing round one used by cattle, and also storing a larger imount of rain-water. It would, at all events, be something until the excellent suggestions of Professor Woodhead were carried out. Water supplies should be administered hy County Councils or al still wider authority.

Professon Woonucad (Cambridge) said he was delighted that there had be'n such av interesting discussion on his somewhat disjointed opening remarks. Without attempting to answer the whole of the questions raised by individnal speakers, he would try to clar up one or two points concerning which he lad evidently not made himself clear, and to supplement what he hald alrealy said on two points. It was perhaps scarcely advisable to enter into the question of standards of bacterial and chemical purity, but he thought they were now fairly entitled to state that that was not now determined by the number of micro-orgavisms or the imount of organic matter that was met with in any single sample of water. They relied fir more upon is "constant" condition, and if a water did not rary from time to time, and if by lung experience be linew where the organic matter "ame from, and that the micro-organisms were all water organisms, he felt far more satisfied than he should with a very much better sample of which be had seen only a single analysis. Bail results always indicated a bad water, but good results obtained on one or two occasions only did not necessarily indicate that we had to deal with a good water. The number of organisms, say 100 per ce., may mean much, but it may mean very little, unless it be read in connection with the number of species, the liud of micro-organismi, their source, surface pollutions, sewage pollution, and so on. In all cases the constancy as to numbers of the forms of the micro-organisms, and of the total number and the constancy of the chemical composition, gave the most raluable information. He agreed with one of the speakers, who stated that it was necessary to comljine the information that could be obtained from various sources, but a sharp line of distinction must be klrawn between a request for a more analysis and a demand for a reasoned opinion. It was for that reason that lin. was anxious that they should have a Central Water Board, consisting, say, of it chemist, a geologist, a hacteriologist, and al hogal expert as a nucleur, with al 
serios of "local" members appointed by county anthoritios. They haul bern told that hunan nature being what it was, they would find it difficult to put into force the regulations drawn up by any central organisation. What he derired to see was a contral organisation which had feclers thrown out in all dinetions. and he had a kind of latent hope that under such conditions oflicial nature might to some cxtent counteract the baser side of human nature. It was his experience of the small powers possessed by County Councils that led him to desire that these powers should be increased either directly ol indirectly, and as water-collecting areas were seldom the same as county areas, and as therefore there was necessarily great overlapping, he would like to law" a central authority which could art with and cont rol the county rommittees. The rentral authority would have lefore them all the information that could be obtained; they would be able to co-ordinate such information and to mete out justice, especially with the aid of thuse on the spot, who were acquainted with the exact requirenents of the various districts. A ministre of lydrology, as chairman of such a Board, would nol have an asy time of it, hut he would be alste 10 aceomplish work of immons. value to the communty. From the pemarlis of sevelial speakers he thought that he could not have made himself quite clear on one point. They seemed to think that le wislied to minimise the value of their surface supplies. His object, on the other hind, wals to draw attention to the fact that in the fen district, for exanple, the rivers must necessarily be the main sourees of supply, ind it was for that reason that he desired to see these rivers protected from pollution. Moreover, he considered that surface wells might be utilised to a much greater extent than they were. He brought forward the evidence adduced by the late Dr. Vivian Poore on that point. It was for that reason, too, that he spoke of those surface filters and of pure-water tanks, which, of course, might take the form of steel-tubed wells, though his idea was that deep wells might involve unnecessary pumping. Where, however, the question of space cropped up, these deep wells might lue utilised with great advantage. There could be little doubt that typhoid, as one speaker remarked, was a rural disease. It became epidemic in larger communities only after it had been nurtured and had broken out in rural districts. They had done much to combat its rariges in towns, and something had been done in rural districts, but wuch still remained to be done. If this question of rural water supply could be thoroughly ventilated it was one, he believed, that would ultimately give a valuable return. England was a small country with a rapilly growing population, and unless the sewage could be prevented from getting into the water supplies, there would soon come a point at which they would have to set to work to undo what they might, with an expenditure of much less money and inergy, prevent.

Mr. J. E. Purvis (Cambridge), in reply, said that there were some questions raised in the discussion which he thought should be more fully discussed. One was with regard to the statement by Mr. Moor as to the organic 


\section{Rural Water Supply and Internetation of Wuter Anulyses.}

matter in water and its effect in lowering the state of health. He seemed to doubt that statement because he said it was stated in text-books. He (Mr. Purvis) suggested that statements in text-bonks were often trur, and it did not follow that because the statement was in text-bonks it must be riewed with suspicion. The point to be remembered was that it was not only a statement in text-looks, but it was a statement based on the authority of medical men. He would point out that although people did not drink the large volume of water suggested by Mr. Moor, it was the rontinual use of the water which caused the danger. And where they had an allilysis slowing dingerous contamination by organic matter and cblorides, the matter becamr particularly serious when the water was used by infants and invalids. If they supplied infants and invalids with such water ther were giving them a very dangerous and polluted water, whatever the bacterial examination might show. And then with regard to standards, if they had tables which represented a thousand analyses, as suggested by Mr. Moor, somclody would want a table which repre. sented two thousand analyses, and so on. Besides, it would be almost a physiral impossibility to compare an analysis with a thousand analyses; it would take a werk to do it. They were living in a work-a-day world, and they had to put up with compromises. The must take a single analysis and judge it on its own merits: what it was and what it might be, and also compare it bacterially. There was another point brought out by Dr. Kinnicutt, of Massachusetts, whom he was extremely glad to lave heard. The publications issued by the Massachusetts Board of Health were not only ideals, but they also gave us methods. They taught many important methods; and the method implied the ideal. If in England use could be made of some of these methods and equally satisfactory results be obtained, the people would be considerably better off as regarded theil. public health. The particular point he ( $D_{1}$. Kinnieutt) mentioned was with regard to the oxygen-absorbed test. That was also the point that the Chairman of the Cambridge County Council wished to be cleared up. Also Mr. Moor said that oxygen absorbed did not affect the lower forms of life. It was not suggested that it did. The oxygen-absorbed test scarcely applied to these low $\mathrm{r}$ forms. In the first place it was usually applied to nitrites and to ferrous iron primarily. Then it represented the amount of oxygen which was taken from the potassium permanganate and used to oxidise organic matter in solution to water and carbon dioxide; and the measure of it distinguished if the organic matter was in a stable or an unstable condition. Then again, with regard to Dr. Ininnicutt's question as to the Massachusetts Board of Health not laying so much stress upon it. He (Mr. Purvis) was very interested in that statement, because he had always taken the opposite riew. He had always considered that the oxygen absorbed was a most important figure, and for the reason that it dealt with three points: first with nitrites, secondly with ferrous iron, and thirdly with the dissolved organic matter. As regarded the dissolved organic matter, if they had a high figure for that experiment, in two or three hours 
at $80^{\circ} \mathrm{F}$, what it usually meant to the chemist was that the urganir mat ter (sily sucb highly complex bodies as organir nitrogenous compounds) was in an unstable state, and that it was breaking down; whereas if they got a low figure. it meant they were dealing with organic matter which was more or less stable, and it might be of purely vegetalılo origin. That was the rason wly they litid such stress upon the quantity of oxygen absorbed. Then with regard to a point brought forward by Mr. West Kniglits, and also WM Mr. Maltin, that it was not necessary for the analyst to know anything alout the history of any water sent for analysis. Ho would go with them thus far: that if the instructions to the analyst were that he sloould simply state his results with no report, or at any rate with only a provisional judgment, he would agree; but if he had to give a judgment, and that judgment was to be uf far-reaching jumportance, then le said the analyst should know the origin and the history of the particular water. IIo was very pleased to hear that Dr. Kinnicutt laid great stress upon the instructions for collerting samples of water' it was most important. Ho would give one example of rarclessnesis in collu.ting witter: lee had a sample once sent to him for analywis contained in a bottle which had previously contained eau de Cologne: 